\title{
Description of Patients with Chronic Suppurative Otitis Media at H. Adam Malik Hospital Medan 2016-2018
}

\author{
Muhammad Husni*, M. Pahala Hanafi Harahap*, Askaroellah Aboet* \\ * Department of Ear Nose Throat Head and Neck Surgery, \\ Faculty of Medicine, Universitas Sumatera Utara, Medan, Indonesia \\ DOI: 10.29322/IJSRP.11.08.2021.p11669 \\ http://dx.doi.org/10.29322/IJSRP.11.08.2021.p11669
}

\begin{abstract}
-
Background: Chronic suppurative otitis media (CSOM) is a common cause of hearing loss in developing countries. CSOM is a disease with high prevalence, and if not treated properly, it can lead to various complications that lead to decreased quality of life and death. The incidence of chronic suppurative otitis media in multiple regions in Indonesia is still relatively high. It can be estimated that there are 6.6 million people with CSOM from the 220 million population of Indonesia.

Objective: This study aimed to determine the characteristics of chronic suppurative otitis media patients at RSUP H. Adam Malik Medan from January 2016 to December 2018.

Method: This study was a retrospective descriptive study using 188 medical records of patients diagnosed primarily with chronic suppurative otitis media at H. Adam Malik General Hospital Medan from January 2016 to December 2018.

Results: From 188 patients with CSOM, 69 patients (36.7\%) were in the 17-25 year age group. Most sufferers were male, about 125 patients $(66.5 \%)$. Based on the level of education, the highest proportion was in primary school, with about 55 patients $(29.3 \%)$. Based on the occupation, the highest proportion did not work as much, 62 patients (33\%). The main complaint was ear discharges of about 109 patients $(58 \%)$. The most common type of perforation was a central perforation, about 72 patients (38.3\%). The highest proportion by type was a benign type of CSOM, about 112 patients (59.6\%). Mastoiditis complications were the most common complications, about 98 patients $(52.1 \%)$. The highest proportion of therapy with drugs was 83 patients $(44.2 \%)$. The highest culture was 149 patients $(79.2 \%)$ with Pseudomonas aeruginosa as a result.
\end{abstract}

Keywords: Chronic suppurative otitis media, characteristics, ear discharges, hearing loss.

Index Terms- About four keywords or phrases in alphabetical order, separated by commas. Keywords are used to retrieve documents in an information system, such as an online journal or a search engine. (Mention 4-5 keywords)

\section{INTRODUCTION}

Chronic suppurative otitis media (CSOM) is one of the most common causes of hearing loss, especially in developing countries. The incidence rate of CSOM is $4.76 \%$, equivalent to 31 million cases, of which $22.6 \%$ of cases occur annually. Thus, the prevalence of CSOM globally reaches $60 \%$, where sufferers experience significant hearing loss [1]. Bacteria $P$. aeruginosa is the most common cause of CSOM in adults [2].

CSOM is considered the most common cause of mild to moderate persistent hearing loss among children and young people in developing countries. CSOM causes around 164 million cases of hearing loss, and $90 \%$ of them occur in developing countries. Data from WHO shows that the prevalence of CSOM in developing countries such as Malaysia, the Philippines, Thailand is still relatively high, namely 2-4\% compared to developed countries in Europe such as England, Denmark, Finland, which is around 0.4\% which is relatively low [3]. Epidemiological studies in Southeast Asian countries, namely Malaysia, Thailand, the Philippines, and Vietnam, in 2012, it was estimated that the prevalence of CSOM was around 2-4\%. The Ministry of Health also reported the same thing through the Sight and Hearing Health Survey in Indonesia. The prevalence of CSOM in 2006-2009 was 3.1\%. Therefore, it can be estimated that there are 6.6 million CSOM sufferers out of 220 million Indonesians [4].

Browning stated that low socioeconomic life, slum environment, and poor health and nutritional status are the factors that form the basis for the increasing prevalence of CSOM in developing countries [5]. Therefore, Aboet said a survey conducted in seven provinces in Indonesia in 1996 found that the prevalence of chronic suppurative otitis media was 3\% of the Indonesian population [6]. Profile of CSOM patients with complications at Dr Hasan Sadikin General Hospital Bandung in January - December 2011 showed that $36.75 \%$ of patients had complications, with otorrhoea as the most frequent chief complaint (95.3\%), and hearing loss was the most frequent additional symptom accompanying CSOM patients. Upper respiratory tract infection is the most common risk factor. Most cases had intratemporal complications as much as $72 \%$. Granulation tissue was the most frequent intratemporal complication (32.5\%) [7].

Asroel et al. conducted a study from 2006 - 2010 at H. Adam Malik Hospital in Medan and found an increase in CSOM cases of hazard type every year. In 2006, of 119 CSOM patients, $9.24 \%$ were found to be of the hazard type. Lubis et al. at H.Adam 
Malik Hospital Medan Indonesia also reported that the dominant type of CSOM was the atticoantral type. CSOM was also most common in the age group of children and young adults [6,8]. CSOM can cause hearing functional limitations. It results in problems in communication that can hinder social interaction and daily life both at work and in activities. Often, it can be found that patients with severe hearing loss will withdraw from social activities [9]. CSOM cases which have long been known to be a disease with a high prevalence even if not handled properly can lead to various complications that result in decreased quality of life and even death. However, until now, the incidence of CSOM in multiple regions in Indonesia is still relatively high. Therefore, rapid diagnosis and treatment are expected to improve the quality of life for sufferers and can improve linguistic abilities and academic development for children suffering from CSOM.

\section{MATERIALS AND METHODS}

This research was a descriptive study. Data were collected retrospectively from medical records or secondary data for CSOM patients. The sample in this study was CSOM patients at H. Adam Malik Hospital from January 2016 - December 2018 . Inclusion criteria were all patients who came to the polyclinic and were diagnosed with primary CSOM and treated at H. Adam Malik Hospital for January 2016 - December 2018. The exclusion criteria were incomplete medical records according to the research variables. Data was collected using secondary data obtained from documented in the patient's medical record and tabulated according to the variables to be studied. The data was processed and calculated descriptively by using the SPSS version 22 program.

\section{RESULTS}

This research was carried out at H. Adam Malik Hospital Medan in December 2019-January 2020. Data were obtained at H. Adam Malik Hospital Medan as many as 188 cases. The data were obtained from secondary data through the medical records of patients with a primary diagnosis of chronic suppurative otitis media at H. Adam Malik Hospital Medan in January 2016 - December 2018. The results of the study are presented in tabular form as follows:

Table 1. Distribution of Proportion of CSOM Patients at H. Adam Malik Hospital Medan in January 2016 - December 2018

\begin{tabular}{|c|c|c|}
\hline Characteristics & $\mathbf{n}$ & $\%$ \\
\hline \multicolumn{3}{|l|}{ Gender } \\
\hline Male & 125 & 66.5 \\
\hline Female & 63 & 33.5 \\
\hline \multicolumn{3}{|l|}{ Age } \\
\hline $0-5$ years & 0 & .0 \\
\hline $6-11$ years & 8 & 4.3 \\
\hline $12-16$ years & 42 & 22.3 \\
\hline $17-25$ years & 69 & 36.7 \\
\hline $26-35$ years & 45 & 23.9 \\
\hline $36-45$ years & 24 & 12.8 \\
\hline $46-55$ years & 0 & .0 \\
\hline $56-65$ years & 0 & .0 \\
\hline$>65$ years & 0 & .0 \\
\hline \multicolumn{3}{|l|}{ Level of Education } \\
\hline No school & 43 & 22.9 \\
\hline Elementary school & 55 & 29.3 \\
\hline junior high school & 54 & 28.7 \\
\hline senior High School & 36 & 19.1 \\
\hline \multicolumn{3}{|l|}{ Occupation } \\
\hline Private employees & 37 & 19.7 \\
\hline Farmer & 31 & 16.5 \\
\hline
\end{tabular}




\begin{tabular}{|c|c|c|}
\hline Self-employed & 58 & 30.8 \\
\hline Does not work & 62 & 33.0 \\
\hline \multicolumn{3}{|l|}{ Main complaint } \\
\hline Otorrhea & 109 & 58.0 \\
\hline Hearing disorder & 16 & 8.5 \\
\hline Headache & 29 & 15.4 \\
\hline Fullness in the Ear & 24 & 12.8 \\
\hline Vertigo & 8 & 4.3 \\
\hline Seizure & 2 & 1.0 \\
\hline \multicolumn{3}{|l|}{ Perforation Location } \\
\hline Central & 72 & 38.3 \\
\hline Marginal & 4 & 2.1 \\
\hline Attic & 2 & 1.1 \\
\hline Sub-Total & 40 & 21.3 \\
\hline Total & 70 & 37.2 \\
\hline \multicolumn{3}{|l|}{ CSOM type } \\
\hline Benign & 112 & 59.6 \\
\hline Malignant & 76 & 40.4 \\
\hline \multicolumn{3}{|l|}{ Complications } \\
\hline No Complication & 67 & 35.6 \\
\hline \multicolumn{3}{|l|}{ Intratemporal Complications } \\
\hline Mastoiditis & 98 & 52.1 \\
\hline Parese N.VII + Mastoiditis & 12 & 6.4 \\
\hline \multicolumn{3}{|l|}{ Intracranial Complications } \\
\hline Meningitis & 2 & 1.1 \\
\hline \multicolumn{3}{|l|}{ Intratemporal + Intracranial Complications } \\
\hline Mastoiditis + meningitis & 9 & 4.8 \\
\hline \multicolumn{3}{|l|}{ Therapy } \\
\hline Medicine & 83 & 44.2 \\
\hline \multicolumn{3}{|l|}{ Surgery } \\
\hline Wall-up canal tympanomastoidectomy & 29 & 15.4 \\
\hline Wall-down canal tympanomastoidectomy & 76 & 40.4 \\
\hline \multicolumn{3}{|l|}{ Culture Results } \\
\hline Pseudomonas aeruginosa & 149 & 79.2 \\
\hline Acinetobacter baumanii & 17 & 9.0 \\
\hline Proteus mirabilis & 8 & 4.3 \\
\hline Klebsiella & 8 & 4.3 \\
\hline Citrobacter freundii & 6 & 3.2 \\
\hline \multicolumn{3}{|l|}{ Audiometry Results } \\
\hline Conductive Deafness & 99 & 52.7 \\
\hline Sensorineural Deafness & 40 & 21.2 \\
\hline
\end{tabular}




\section{DISCUSSION}

The highest proportion of CSOM patients by gender was male, as many as 125 people (66.5\%). Based on the results of research by Aruan (2015), it was found that there were more male CSOM patients than women, namely as many as 20 people or 66.7\% [10]. Srivastava et al. (2010) stated that men suffer from CSOM more often because men have a habit of working outside the home, so that men are more frequently exposed to risk factors for their occurrence [11].

The highest proportion of CSOM patients based on age was in the young adult age group, 17-25 years, as many as 69 people (36.7\%). This result could have happened because some patients had a history of discharge from the ear (otorrhoea) since childhood and came when they were adults with these complaints and were diagnosed with CSOM, which is a continuation of complaints that occurred as a child. The high incidence of CSOM at the age of > 18 is also caused by exposure to environmental infections, poor hygiene and poor health behaviour, and a history of chronic infections that are not treated adequately [12].

Based on the last education level, the highest proportion of CSOM patients was an elementary school with 55 (29.3\%). The results of this study are in line with research conducted and research at RSUD dr. M. Haulussy Ambon stated that the education level of CSOM sufferers with the highest frequency and percentage was 20 people (37.0\%). He concluded that CSOM tends to occur in people with low levels of education or knowledge. The low level of education affects the lack of knowledge about nutrition, healthy lifestyles, ARI diseases that can cause otitis media, causing the public not to pay much attention to this disease, thereby increasing the incidence of CSOM. (Malirmasele, 2014).

The highest proportion of CSOM patients by occupation was in the group of patients who did not work, 62 people (33\%). These results are in line with the research of Malirmasele et al. (2014) in RSUD dr. M. Haulussy Ambon, namely 85.2\% or as many as 46 out of 54 people who do not work. Jobs with low-income levels make it challenging to provide suitable housing facilities, adequate health care, and good education. The main problem is not meeting the need for healthy food, which impacts poor nutritional quality, can weaken the body's immune system, and affect the vulnerability of disease, especially CSOM [13].

Based on the main complaint, the highest proportion of CSOM patients was discharge from the ear or otorrhoea as many as 109 people (58\%). The results of this study are also in line with the research of Malirmasele et al. (2014) in RSUD dr. M. Haulussy Ambon, which shows that the main complaint of most CSOM sufferers is otorrhoea as many as 44 people (81.5\%). Otorrhoea or watery ears are early symptoms that often arise and significantly interfere with a person's appearance, especially in patients who experience otorrhoea continuously, thus encouraging them to consult a doctor immediately [13].

The highest proportion of CSOM patients based on the perforation location was central perforation as many as 72 people (38.3\%). It is consistent with the results obtained by Tiedt et al. that the perforation location is more often in the central area [14]. Thus, based on the study results, it appears that central perforation has a high percentage. This finding can be related to the process before the tympanic membrane perforation, namely severe oedema of the middle ear mucosa and destruction of superficial epithelial cells; as well as the formation of purulent exudate in the tympanic cavity, which causes high pressure - in the middle ear, pushing the pars tensa toward the external acoustic meatus. If the exudate pressure is not reduced, then ischemia occurs; it causes the rupture of the tympanic membrane so that the exudate comes out into the external acoustic meatus [13].

The highest proportion of CSOM patients by type was benign, with 112 people (59.6\%). The results of this study are in line with research by Malirmasele et al. (2014) at RSUD dr. M. Haulussy Ambon, where the benign type was 44 people (81.5\%) while the malignant type was ten (18.5\%) [13]. The results of this study are not in line with the research of Laisitawati et al. (2017); of 116 samples suffering from CSOM, 54 people $(46.6 \%)$ were classified as benign CSOM. While CSOM patients belonging to the malignant type were higher, namely 62 people $(53.4 \%)$ [12]. The most common benign type is because the disease continues acute otitis media, usually with fever and a central perforation. The perforation becomes permanent and allows exposure to infection from the outer ear. The middle ear mucosa is also exposed to the external environment, resulting in persistent otorrhoea. Infections spread through the eustachian tube, such as tonsils, adenoids, and sinuses, resulting in persistent or recurrent otorrhoea [15].

Based on complications, the highest proportion of CSOM patients were patients with intratemporal complications, namely mastoiditis, as many as 98 people (52.1\%). These results are also in line with the study results at Adam Malik Hospital Medan, which showed that $25.4 \%$ of CSOM patients with complications were mastoiditis [8]. Furthermore, based on the research results of Islam et al. (2010), in Bangladesh, the most complications were intratemporal complications, namely mastoid abscess as many as 11 people (50\%) [16]. Following the study of Yulius et al., 2018, 87.5\% of patients with otitis media with cholesteatoma suffered from intratemporal complications, and only $12.5 \%$ had intracranial complications [17]. In this study, the most complications were intratemporal complications, namely mastoiditis. It is in accordance with various studies which state that intratemporal complications are the most common complications that occur with various mechanisms, including from venules in the temporal bone that have a connection to the petrous, and this venous connection allows spread with bone that remains intact $[18,19]$. The mastoid air cell system and the middle ear are interconnected so that all inflammatory processes that occur in the middle ear will affect the mastoid as well. Mastoiditis in CSOM is an extension of the infection process that persists in the middle ear. Not only in the mastoid structure but also in other structures around the mastoid [20].

Based on the therapy given, the highest proportion of CSOM patients was medication therapy as 83 people (44.2\%). Based on the type and treatment given, the benign type underwent pharmacotherapy, but some patients underwent tympanomastoidectomy 
surgery. Supposedly, CSOM patients with benign type can be treated with pharmacotherapy. This result could be due to several things. In safe type CSOM, the literature said that simple mastoidectomy surgery could be performed if conservative treatment does not heal [21]. In this study, 76 patients with malignant CSOM at HAM Hospital and all patients underwent surgery. In patients with malignant CSOM, the principle of therapy is surgery. Conservative therapy with medication is only brief therapy before surgery. However, in malignant CSOM patients, some patients only undergo pharmacotherapy treatment. It can also happen for various reasons. The presence of patients who refuse to undergo surgery can be due to problems with approval from the family or low costs; besides that, there may be patients with malignant type CSOM who have other diseases that do not allow surgery [21].

Based on culture results, the highest proportion of CSOM patients was Pseudomonas aeruginosa, with as many as 149 people (79.2\%). The results of this study are in line with the research of Dewi and Zahara (2009); the results of the clinical microbiology laboratory culture of the HAM Hospital from ear discharge cultures were Pseudomonas aeruginosa, as many as 8 (34.8\%) [22]. This finding is similar to the study by Loy et al. (2002) that the most gram-negative aerobic bacteria was Pseudomonas aeruginosa as many as 30 (33.3\%) and the most gram-positive aerobic bacteria was Staphylococcus aureus with the same percentage (33.3\%) [23].

Based on pure tone audiometry results, the highest proportion of CSOM patients was conductive deafness as many as 99 people (52.7\%) with an average hearing threshold of $35 \mathrm{~dB}$ for mild deafness. The results of this study are in line with research by Laisitawati et al. (2017); the type of hearing loss is dominated by conductive deafness $(67.2 \%)$ followed by mixed deafness $(22.4 \%)$ and sensorineural deafness (10.3\%) [12]. The type and degree of hearing loss in CSOM can vary between conductive deafness, sensorineural deafness, and mixed deafness, with mild, moderate, moderate, severe, severe, and very severe degrees. Conductive hearing loss is the most common form, but sensorineural hearing loss and mixed hearing loss may occur [24].

In the current study, the most conductive deafness due to CSOM hearing loss can occur due to infection in the middle ear. This infection causes an increase in a serous fluid; over time, mucus and serous fluid accumulate so that the received sound/air conduction decreases. In addition, in CSOM, granulation tissue is often found, and the ossicular chain breaks. It is undoubtedly related to sound wave transmission disorders which manifest as a decrease in the degree of hearing loss [16]. Sensorineural deafness in CSOM occurs because hearing loss continues to worsen with CSOM with long duration; this is due to several factors such as ossicular resorption and necrosis due to prolonged infection in the middle ear, mastoid air cell sclerosis, which causes a decrease in mastoid air cell volume, and also due to the passage of bacterial toxins into the scala tympani through the round window membrane where infection of the middle ear can cause the release of inflammatory mediators such as nitric oxide and arachidonic acid metabolites which can cause functional changes and morphology of auditory structures. Inflammatory mediators can also penetrate the round window membrane and enter the inner ear causing cochlear damage. Other studies have shown that bacterial toxins that cause CSOM can penetrate the cochlea and cause damage. These bacterial toxins can be in the form of exotoxins produced by gram-positive and gram-negative bacteria or endotoxins on the outer membrane of gram-negative bacteria. Infections caused by this toxin can cause direct damage to hair cells, especially the basal cochlea [25]. Mixed deafness occurs due to a mixture of conductive disorders in the external acoustic meatus, the tympanic membrane's perforation, sensorineural disturbances, and CSOM with a long duration [26].

\section{CONCLUSION}

This study concluded that the most common CSOM was the benign type, which is expected for doctors who examine and treat patients to treat patients completely to surgical management, which in this study has the most canal wall downs. Then, the hospital must improve the management of recording and store medical records. The medical record format owned by H. Adam Malik Hospital can facilitate researchers conducting research using medical records. Future studies should continue this research with different methods and variables to identify other factors that play a role in CSOM.

\section{ACKNOWLEDGMENT}

The preferred spelling of the word "acknowledgment" in American English is without an "e" after the "g." Use the singular heading even if you have many acknowledgments.

\section{REFERENCES}

[1] Leach AJ, Morris PS, Coates HL, Nelson S, O’Leary SJ, Richmond PC, et al. Recommendations for Clinical Care Guidelines on Management of Otitis Media. Australian Department of Health Government 2012.

[2] Sahu SK, Narasimham M venkata, Mohanty I, Padhi S, P P, a, et al. Microbiological profile of chronic suppurative otitis media and invitro antibiotic sensitivity pattern in a tertiary care hospital. Otolaryngology Online Journal 2014;4:1-14.

[3] World Health Organization. Chronic suppurative otitis media: burden of illness and management options 2004.

[4] Dinas Kesehatan Provinsi Sulawesi Selatan. Beranda | Dinas Kesehatan Provinsi Sulawesi Selatan n.d. http://dinkes.sulselprov.go.id/ (accessed August 9, 2021).

[5] Aboet A. Radang telinga tengah menahun. Pidato Pengukuhan Jabatan Guru Besar Tetap Bidang Ilmu Kesehatan Telinga Hidung Tenggorok Bedah Kepala Leher Medan: Fakultas Kedokteran Universitas Sumatera Utara 2007. 
[6] Asroel HA, Siregar DR, Aboet A. Profil penderita otitis media supuratif kronis. Kesmas: Jurnal Kesehatan Masyarakat Nasional (National Public Health Journal) 2013;7:567-71.

[7] Desbassarie F, Dermawan A, Hadi S. Profile of Patients with Complicated Chronic Suppurative Otitis Media in Dr. Hasan Sadikin General Hospital Bandung, Indonesia January-December 2011. Althea Medical Journal 2015;2:108-13.

[8] Lubis YM, Dharma CA, Refilda FE. Profile of chronic suppurative otitis media patients with positive fungal culture in Medan, Indonesia. J Chemical Pharmaceutical Res 2016;8:23-6.

[9] Baumann I, Gerendas B, Plinkert PK, Praetorius M. General and disease-specific quality of life in patients with chronic suppurative otitis media-a prospective study. Health and Quality of Life Outcomes 2011;9:1-6.

[10] Aruan SY, Aboet A, Zahara D, Aliandri A, Saragih AR. Hubungan ekspresi Tumor Necrosis Factor Alpha (TNF- $\alpha$ ) dengan destruksi tulang akibat kolesteatoma. Oto Rhino Laryngologica Indonesiana 2015;45:36-42.

https://doi.org/10.32637/orli.v45i1.104.

[11] Srivastava A, Singh RK, Varshney S, Gupta P, Bist SS, Bhagat S, et al. Microbiological evaluation of an active tubotympanic type of chronic suppurative otitis media. Nepalese Journal of ENT Head and Neck Surgery 2010;1:14-6.

[12] Laisitawati A, Ghanie A, Suciati T. Hubungan Otitis Media Supuratif Kronik dengan Derajat Gangguan Pendengaran di Departemen THT-KL RSUP Dr. Mohammad Hoesin Palembang Periode 2014-2015. Majalah Kedokteran Sriwijaya 2017;49:57-65.

[13] Malirmasele M, Limmon R, Manuputty AG. KARAKTERISTIK PENDERITA OTITIS MEDIA SUPURATIF KRONIS DI KLINIK TELINGA HIDUNG TENGGOROK RUMAH SAKIT UMUM DAERAH DR. M. HAULUSSY AMBON TAHUN 2012 2014:9.

[14] Tiedt NJ, Butler IRT, Hallbauer UM, Atkins MD, Elliott E, Pieters M, et al. Paediatric chronic suppurative otitis media in the Free State Province: Clinical and audiological features. South African Medical Journal 2013;103:467-70.

[15] Dhingra PL. Diseases Of Ear, Nose And Throat With Web Access. Elsevier (A Divisionof Reed Elsevier India Pvt. Limited); 2014.

[16] Islam MS, Islam MR, Bhuiyan MAR, Rashid MS, Datta PG. Pattern and degree of hearing loss in chronic suppurative otitis media. Bangladesh Journal of Otorhinolaryngology 2010;16:96-105.

[17] Yulius S, Asroel HA, Aboet A, Zaluchu F. Correlation of Matrix Metalloproteinase-9 (MMP-9) expression and bone destruction in Chronic Suppurative Otitis Media (CSOM) patients with cholesteatoma at Adam Malik General Hospital Medan-Indonesia. Bali Med J 2018;7:195-200.

[18] Dubey SP, Larawin V. Complications of chronic suppurative otitis media and their management. The Laryngoscope 2007;117:264-7.

[19] Sandhu D, Gupta V, Chhina DK, Munjal M. Clinico-microbiological profile of Chronic Suppurative Otitis media in a Tertiary Care Hospital. IntJResDevPharmLSci 2018;7:2995-8.

[20] Johnson JT, Rosen CA. Bailey's Head and Neck Surgery-Otolaryngology Review. 5th ed. Lippincott Williams \& Wilkins; 2014.

[21] Gustomo BS. Gambaran otitis media supuratif kronis tipe bahaya di RSUD Dr. Moewardi Surakarta Tahun 2007-2009. 2010.

[22] Dewi NP, Zahara D. Gambaran pasien otitis media supuratif kronik (OMSK) di RSUP H. Adam malik Medan. E-Jurnal Fakultas Kedokteran USU 2009;1.

[23] Loy AHC, Tan AL, Lu PKS. Microbiology of chronic suppurative otitis media in Singapore. Singapore Med J 2002;43:296-9.

[24] Alabbasi AM, Alsaimary IE, Najim JM. Prevalence and patterns of chronic suppurative otitis media and hearing impairment in Basrah city. J Med Med Sci 2010;1:129-33.

[25] Hasan N, Ahmed S, Zaman S, Ferdousi S, Khaleque MA, Bari L. CSOM Causing Tympanic Membrane Perforation and Impaired Hearing: Improved by Homeopathy. Journal of Advances in Medicine and Medical Research 2017:1-9.

[26] Shariff M. Analysis of hearing loss by pure tone audiometry in patients with chronic suppurative otitis media. Natl J Physiol Pharm Pharmacol 2019;1. 